\title{
Effects of Cinnamon (Cinnamomum spp.) in Dentistry: A Review
}

\section{Spartak Yanakiev}

Medical College Y. Filaretova, Medical University—Sofia, Yordanka Filaretova Street 3, 1000 Sofia, Bulgaria; s.yanakiev@mc.mu-sofia.bg; Tel.: +35-98-8644-5108

Received: 26 July 2020; Accepted: 11 September 2020; Published: 12 September 2020

\begin{abstract}
Dental medicine is one of the fields of medicine where the most common pathologies are of bacterial and fungal origins. This review is mainly focused on the antimicrobial effects of cinnamon essential oil (EO), cinnamon extracts, and pure compounds against different oral pathogens and the oral biofilm and the possible effects on soft mouth tissue. Basic information is provided about cinnamon, as is a review of its antimicrobial properties against the most common microorganisms causing dental caries, endodontic and periodontal lesions, and candidiasis. Cinnamon EO, cinnamon extracts, and pure compounds show significant antimicrobial activities against oral pathogens and could be beneficial in caries and periodontal disease prevention, endodontics, and candidiasis treatment.
\end{abstract}

Keywords: cinnamon essential oil; dentistry; oral pathogens; oral biofilm; candida; antimicrobial effect; dental caries; endopathogens; cinnamaldehyde; eugenol

\section{Introduction}

Dental medicine is one of the fields of medicine where the most common pathologies are of bacterial and fungal origins. Widely spread diseases like dental caries, periodontal disease, and endodontic lesions are caused by well-known bacterial and fungal pathogens: Streptococcus mutans, Streptococcus salivarius, Streptococcus sanguinis, Porfiromonas gingivalis, Prevotella intermedia, Actinobacilus actinomycetemcomitans, Enterococcus faecalis, Candida albicans, etc. [1]. Preventive medicine relies mostly upon reducing the bacterial biofilm via oral hygiene. The most often used active ingredients in mouth rinses and toothpastes are chlorhexidine, hyaluronic acid, and fluorides. Although effective, chemical products may have some clinical disadvantages: teeth discoloration, taste alterations, mouth dryness, supragingival calculus accumulation, and oral mucosal lesions [2-4].

The attention of many researchers has focused on the antimicrobial properties of traditional medical substances, like essential oils (EOs) [5-7]. EOs and extracts have demonstrated effective antibacterial and antifungal properties [8-11]. In the field of dental medicine, oral hygiene products based on herbal extracts are well-known [12-14]. One of the substances most used by dental professionals is eugenol, which is an active component in root canal sealers, cements, and others. One of the EOs subjected to investigation in dentistry is cinnamon (Cinnamomum spp., Lauraceae family) [15].

Cinnamon is a widely known culinary herb and traditionally used in medicine applications. The effect of cinnamon has been studied during pregnancy [16], for diabetes control [17], and gynecological problems [18]. Its anti-inflammatory, cardioprotective, antioxidative, and antimicrobial properties have also been researched [19]. Thus, cinnamon EO, cinnamon extracts, and pure compounds, due to their antibacterial, antifungal, and other properties, have potential uses in mouth rinses, toothpastes, or as a root canal irrigant, showing promise as an antimicrobial agent in dentistry.

This review focused mainly on the antimicrobial effects of cinnamon EO, extracts, and pure compounds against different oral pathogens and the oral biofilm and the possible effects on mouth tissues. 


\section{Basic Characteristics of Cinnamon and Its Chemical Composition}

Cinnamon (Cinnamomum spp., Lauraceae family) includes more than 250 evergreen trees spread mainly in Asia, China, and Australia [20]. Many species have been studied in the literature, and some of them in the field of dental medicine. Two of the most studied types of cinnamon are Cinnamomum verum or Cinnamomum zeylanicum (true cinnamon, Ceylon cinnamon, or Mexican cinnamon). C. verum's older botanical name, C. zeylanicum, derives from Sri Lanka's older name, Ceylon. Well-studied is also Cinnamomum aromaticum or Cinnamomum cassia (Cassia cinnamon or Chinese cinnamon). The other two main species of cinnamon are Cinnamomum burmannii (also called Korintje, Java, or Indonesian cinnamon) and Cinnamomum loureiroi (Vietnamese or Saigon cinnamon) [19,21,22].

EOs and extracts have been isolated from the different parts of cinnamon, such as the leaves, bark, fruits, root bark, flowers, and buds. More than 80 compounds have been identified, and the compositions vary due to many factors [20]. The main components of cinnamon EOs and extracts are cinnamaldehyde, eugenol, phenol, and linalool. Cinnamon bark EO has a higher cinnamaldehyde content $(65-80 \%)$ and a low eugenol content $(5-10 \%)$. The extract from leaves is rich in eugenol (10-95\%). Roots are rich in camphor [23-25]. The leaf extracts may also have a high cinnamaldehyde content [26]. Table 1 presents the most abundant compounds found in different cinnamon species and parts of the plant.

Table 1. Most abundant compounds found in different cinnamon species and parts of the plant.

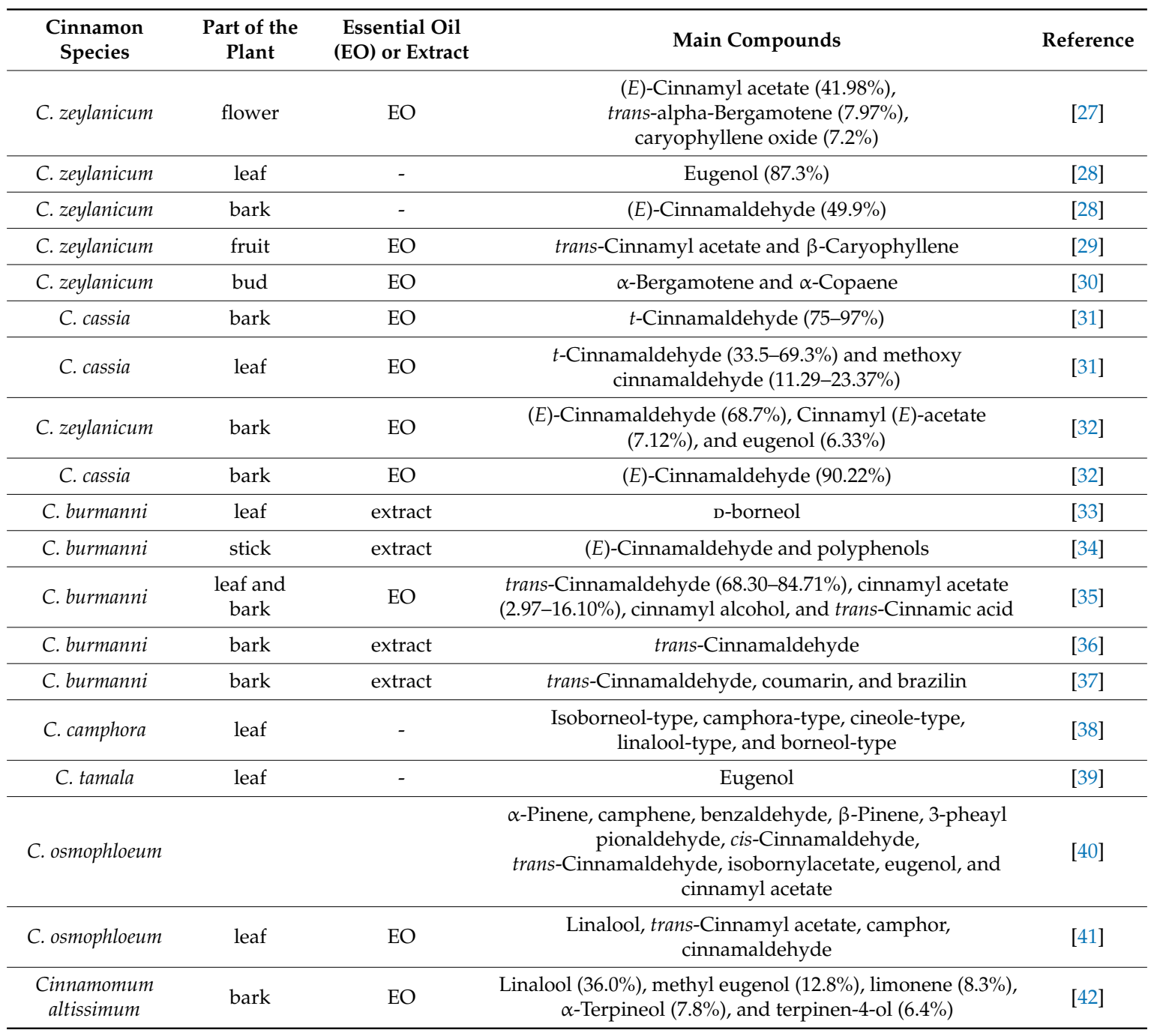


Table 1. Cont.

\begin{tabular}{|c|c|c|c|c|}
\hline $\begin{array}{l}\text { Cinnamon } \\
\text { Species }\end{array}$ & $\begin{array}{l}\text { Part of the } \\
\text { Plant }\end{array}$ & $\begin{array}{l}\text { Essential Oil } \\
\text { (EO) or Extract }\end{array}$ & Main Compounds & Reference \\
\hline C. cassia & Bark & extract & $\begin{array}{c}(E) \text {-Cinnamaldehyde }(62.96 \%) \text {, coumarin }(11.36 \%), \\
\alpha \text {-Copaene (3.78\%), 3-methoxy-1,2-propanediol }(3.26 \%), \\
\text { and } \alpha \text {-Cuaiene }(3.19 \%)\end{array}$ & [43] \\
\hline C. loureiroi & bark & extract & $\begin{array}{c}\text { (E)-Cinnamaldehyde }(51.69 \%), \alpha \text {-Copaene }(16.14 \%), \\
\text { cinnamaldehyde dimethyl acetal }(5.66 \%), \beta \text {-Cadinene } \\
(3.19 \%) \text {, and } \alpha \text {-Muurolene }(4.78 \%) \text {. }\end{array}$ & [43] \\
\hline C. burmannii & bark & extract & $\begin{array}{c}(E) \text {-Cinnamaldehyde }(34.44 \%) \text {, eugenol }(25.67 \%), \\
\text { coumarin }(16.82 \%), \text { borneol }(3.28 \%) \text {, and methyl } \\
\text { cinnamate }(3.16 \%)\end{array}$ & {$[43]$} \\
\hline C. wilsonii & bark & extract & $\begin{array}{c}\text { Linalool }(23.66 \%),(E) \text {-Cinnamaldehyde }(19.63 \%) \text {, citral } \\
(15.45 \%),(E) \text {-Cinnamyl acetate }(8.65 \%) \text {, and } 1,8 \text {-Cineole } \\
(5.54 \%)\end{array}$ & {$[43]$} \\
\hline C. verum & leaf & - & $\begin{array}{c}\text { Eugenol }(85.66 \%) \text {, acetyl eugenol }(6.07 \%) \text {, } \\
\text { cinnamaldehyde, } \beta \text {-Caryophyllene }(1.08 \%)\end{array}$ & [44] \\
\hline C. verum & bark & - & $\begin{array}{c}\text { Cinnamaldehyde }(67.57 \%) \text {, eugenol }(16.03 \%), \alpha \text {-Pinene } \\
\text { (5.76\%), linalool }(3.78 \%), \\
\beta \text {-Caryophyllene }(3.66 \%)\end{array}$ & [44] \\
\hline C. dubium & leaf & - & $\begin{array}{c}\text { Geraniol }(24.05 \%) \text {, cinnamyl alcohol }(15.65 \%) \text {, eugenol } \\
(9.17 \%), \beta \text {-Caryophyllene }(5.60 \%) \text {, and } \alpha \text {-Pinene }(4.04 \%)\end{array}$ & [44] \\
\hline C. dubium & bark & - & $\begin{array}{c}\beta \text {-Caryophyllene }(41.31 \%), \text { cinnamyl alcohol }(8.61 \%), \\
\text { hydro cinnamic aldehyde }(7.70 \%) \text {, eugenol }(5.08 \%) \text {, and } \\
\text { garaniol }(3.86 \%)\end{array}$ & {$[44]$} \\
\hline C. rivolorum & leaf & - & $\begin{array}{l}\text { Eugenol }(63.45 \%), \alpha \text {-Pinene }(3.17 \%) \text {, geraniol }(2.06 \%) \text {, } \\
\text { cinnamaldehyde }(1.57 \%) \text {, and } \beta \text {-Caryophyllene }(1.24 \%)\end{array}$ & {$[44]$} \\
\hline C. rivolorum & bark & - & $\begin{array}{l}\text { Cinnamaldehyde }(31.78 \%) \text {, eugenol }(22.29 \%) \text {, } \\
\beta \text {-Caryophyllene }(8.21 \%) \text {, and geraniol }(7.76 \%)\end{array}$ & {$[44]$} \\
\hline C. sinharajense & leaf & - & $\begin{array}{l}\text { Eugenol }(87.53 \%) \text {, cinnamaldehyde }(2.04 \%) \text {, cinnamyl } \\
\text { alcohol }(1.50 \%) \text {, and } \beta \text {-Caryophyllene }(1.04 \%)\end{array}$ & {$[44]$} \\
\hline C. sinharajense & bark & - & $\begin{array}{c}\text { Cinnamaldehyde (57.46\%), cinnamyl acetate }(13.69 \%) \text {, and } \\
\text { B-Caryophyllene }(4.54 \%)\end{array}$ & {$[44]$} \\
\hline C. citriodorum & leaf & - & $\begin{array}{c}\text { Linalool }(30.71 \%) \text {, cinnamyl alcohol }(5.36 \%) \text {, cinnamyl } \\
\text { acetate }(3.20 \%) \text {, citronellol }(2.44 \%) \text {, and cinnamaldehyde } \\
(2.27 \%)\end{array}$ & {$[44]$} \\
\hline C. citriodorum & bark & - & $\begin{array}{l}\text { Cinnamaldehyde }(42.74 \%) \text {, geraniol }(19.95 \%) \text {, linalool } \\
(8.94 \%) \text {, eugenol }(4.0 \%) \text {, and } \beta \text {-Caryophyllene }(3.56 \%)\end{array}$ & {$[44]$} \\
\hline
\end{tabular}

C. zeylanicum and C. cassia are the most-studied types of cinnamon. Doh et al. reported that, based on the analysis of phylogenetic relationships, C. cassia and C. zeylanicum are clustered in different groups [45]. One of the main differences between C. zeylanicum and C. cassia is the coumarin content. C. cassia tends to have a higher percentage of coumarin, thus posing more health risks due to the anticoagulant, cancerogenic, and hepatotoxic properties of coumarin [46]. Jose et al. reported a higher coumarin content in the leaves of C. cassia ( $481-2462 \mathrm{mg} / \mathrm{kg}$ ) in comparison to the bark (3-86 mg/kg) [31]. In comparison, the coumarin contents in the leaves and bark from C. zeylanicum are 13 and $53 \mathrm{mg} / \mathrm{kg}$, respectively. Significantly higher coumarin levels in C. cassia, C. burmannii, and C. loureiroi were reported, whereas C. zeylanicum contains only traces [47].

One of the possible side effects of cinnamaldehyde is hypersensitivity [48]. Although not so common, cases of intraoral allergic reactions due to different cinnamaldehyde-containing products have been reported in the literature [49,50]. Some evidence exists of the instability of trans-cinnamaldehyde when exposed to air or in blood vessels. A chemical reaction involving a transformation to cinnamic acid can occur, leading to reduction in the antibacterial activity [51]. Eugenol produces a possible irritation effect on the periapical tissues and could lead to necrosis of bone and cementum and to an alteration of the eruption of permanent teeth [52]. Reports of allergic contact dermatitis and stomatitis as a result of cinnamon EOs are rare [53,54], which could lead to orofacial granulomatosis [55]. In vivo 
studies reported a lack of significant side effects on the liver and kidneys, no hypersensitivity, and a wide therapeutic range of C. zeylanicum [56,57]. C. zeylanicum has a positive osteogenesis effect on pulp stem cells [58].

\section{Antimicrobial Effect of Cinnamon EO and Cinnamon Extracts against Oral Pathogens}

Cinnamon EO or cinnamon extracts could be used as antimicrobial agents. Steam distillation or organic solvents and alcohols are used for the preparation of the substances. The composition of the extracts or EO depends on the extraction method and protocol used [59].

The antimicrobial properties of cinnamon EO against different oral pathogens are subject to many researchers. These properties are assessed according to the minimum inhibitory concentration (MIC) values. Different degrees of antimicrobial activity of culinary herb EOs against the growth of cariogenic bacteria can be categorized into three groups: strong (MIC $\leq 0.1 \%(v / v)$ ), moderate $(\mathrm{MIC} \leq 1.0 \%(v / v))$, and weak $(\mathrm{MIC}>1.0 \%(v / v))$ [7]. Natural products have strong antibacterial properties if their MIC is $500 \mu \mathrm{g} / \mathrm{mL}$ or less [60]. Hovijitra et al. categorized the efficacy of EO as strong $(\mathrm{MIC}<0.5 \mu \mathrm{L} / \mathrm{mL}$ or $0.05 \%(v / v))$, moderate $(0.5 \mu \mathrm{L} / \mathrm{mL} \leq \mathrm{MIC} \leq 1.0 \mu \mathrm{L} / \mathrm{mL}$ or $0.1 \%(v / v))$, and weak (MIC $>1.0 \mu \mathrm{L} / \mathrm{mL}$ ) [61]. Other researchers used the following classification of antimycotic activity based on the MIC: $<100 \mu \mathrm{g} / \mathrm{mL}$ (good), 100-500 $\mu \mathrm{g} / \mathrm{mL}$ (moderate), 500-1000 $\mu \mathrm{g} / \mathrm{mL}$ (weak), and $>1000 \mu \mathrm{g} / \mathrm{mL}$ (inactive) [62].

\subsection{Antimicrobial Effect against Caries Pathogens}

Wiwattanarattanabut et al. reported good antimicrobial properties of cinnamon EO (C. zeylanicum) against two cariogenic bacteria: S. mutans KPSK and Lactobacillus casei [7]. Cinnamon EO exhibited a MIC and minimum bactericidal concentration (MBC) against S. mutans of $0.08 \%(v / v)$. Two-times higher MIC and MBC against $L$. casei were reported $(0.16 \%(v / v))$. The inhibition zone diameter was $32.17 \pm 1.32 \mathrm{~mm}( \pm \mathrm{SD})$. In comparison, the inhibition zone of $0.2 \%$ chlorhexidine was $29.83 \pm 0.75 \mathrm{~mm}$ $( \pm S D)$. The inhibition zone of cinnamon EO against L. casei was $17.33 \pm 1.03 \mathrm{~mm}$. S. mutans biofilm mass was reduced by $\leq 35 \%$ and $\leq 19 \%$ after the treatment with $0.25 \%$ chlorhexidine for $24 \mathrm{~h}$ and $1 \mathrm{~h}$, respectively. Cinnamon bark EO exhibited the strongest reductive effect, but the effect was not statistically significant $(p>0.05)$ against the $S$. mutans biofilm compared with all the tested herbal EOs. A 24-h exposure to cinnamon EO at its MIC, $2 \times \mathrm{MIC}(0.16 \%(v / v))$ and $4 \times \mathrm{MIC}(0.32 \%(v / v))$ reduced the biofilm mass by approximately $80 \%$. Bacterial film reduction was also reported on implant surfaces [63].

Methanolic extract from C. zeylanicum produced inhibition zone diameters of $14.00 \mathrm{~mm}$ against S. mutans and $16.67 \mathrm{~mm}$ against Lactobacillus acidophilus [64]. The mean MIC (mg/mL) values were 13.44 against $S$. mutans and 5.18 against L. acidophilus. The mean MBC were 23.6 and $16.4 \mathrm{mg} / \mathrm{mL}$, respectively. A combination of cinnamon and clove methanolic extracts resulted in larger inhibition zones. Ethanolic extract of C. zeylanicum showed good antimicrobial activity against S. mutans ATCC-700610: $\mathrm{MIC}=195 \mu \mathrm{g} / \mathrm{mL}$ and $\mathrm{MBC}=390 \mu \mathrm{g} / \mathrm{mL}[65]$.

In another study, nicotine-induced $S$. mutans UA159 biofilm formation proved sensitive to $2.5 \mathrm{mg} / \mathrm{mL}$ cinnamon water extract. Nicotine concentration-dependent reduction of the biofilm from $34 \%$ to $98 \%$ was reported (MIC and MBC were $2.5 \mathrm{mg} / \mathrm{mL}$ ) [66].

C. zeylanicum leaves EO had a MIC of 250-500 $\mu \mathrm{g} / \mathrm{mL}$ and MBC of 500-100 $\mu \mathrm{g} / \mathrm{mL}$ against S. mutans, as reported by Galvão et al. [67].

The inhibitory effect of EO obtained from C. cassia bark added to a toothpaste against S. mutans was reported by Karadağlığlu et al. [68]. The combination of cinnamon EO and the selected commercially available herbal toothpastes resulted in a significant increase of the inhibition zone diameter (mean values between 36.33 and $39.67 \mathrm{~mm}$ ).

Cinnamon EO showed the highest antibacterial activity against $S$. mutans among eight other EOs tested, including lime, spearmint, wintergreen, peppermint, lemongrass, cedarwood, clove, and eucalyptus EOs [69]. In a vast study investigating the antimicrobial properties of 32 EOs against oral 
pathogens, S. mutans, Streptococcus sobrinus, and C. zeylanicum EOs proved to be the most effective based on the inhibition zone measurements [70]. The antimicrobial effects of cinnamon against $S$. mutans and Lactobacillus plantarum proved to be stronger in comparison to tea tree, manuka, arnica, eucalyptus, and grapefruit [71]. In another study, the cinnamon EO did not prove its antibacterial properties against S. mutans [72]. The composition of the EO used in this study was mainly cinnamyl-alcohol (88.45\%), cinnamyl-acetate (6.13\%), and p-Eugenol (2.98\%) One of the main antibacterial chemical compounds, cinnamaldehyde, was only responsible for $0.39 \%$ of the composition.

Data based on the MIC and MBC of cinnamon essential oil against caries pathogens are summarized in Table 2.

Table 2. Minimal inhibitory concentration (MIC) and minimal bactericidal concentration (MBC) of cinnamon $\mathrm{EO}$ and cinnamon extracts against cariogenic bacteria.

\begin{tabular}{lccccc}
\hline $\begin{array}{l}\text { Cinnamon } \\
\text { Species }\end{array}$ & EO or Extract & Bacterial Strains & $\begin{array}{c}\text { MIC } \\
\mathbf{( \% )}\end{array}$ & $\begin{array}{c}\text { MBC } \\
\mathbf{( \% )}\end{array}$ & Reference \\
\hline C. zeylanicum & EO & S. mutans & 0.08 & 0.08 & {$[7]$} \\
C. zeylanicum & Methanolic extract & S. mutans & 0.16 & 0.16 & \\
C. zeylanicum & Ethanolic extract & L. acidophilus & 0.52 & 2.36 & {$[64]$} \\
C. zeylanicum & Water extract & S. mutans & 0.02 & 0.04 & {$[65]$} \\
C. zeylanicum & EO & S. mutans & 0.025 & 0.25 & {$[66]$} \\
\hline
\end{tabular}

\subsection{Antifungal Activity of Cinnamon EO and Cinnamon Extracts}

The combined effect of cinnamon, clove, and oregano obtained by hydrodistillation against several C. albicans strains, Candida tropicalis IP 2148.93, and Candida glabatra DSM 11226 was reported by Brochot A. et al. [24]. The MIC and the minimal fungicidal concentration (MFC) varied between $0.01 \%$ and $0.05 \% v / v$.

In another study [73], the antibacterial and antifungal effects of cinnamon EO, prepared by steam distillation against S. mutans, S. aureus, methicillin-resistant Staphylococcus aureus (MRSA), C. albicans, and C. glabrata, isolated from the oral samples, were assessed. The MIC of C. zeylanicum EO varied from 12.8 to $51.2 \mathrm{mg} / \mathrm{mL}$ (S. mutans was the most sensitive microorganism). The minimal inhibition of growth concentration of the tested microorganisms was $3.12 \%$ against $S$. mutans and $12.5 \%$ against C. albicans and C. glabrata.

The study of the comparative effects of cinnamon (C. zeylanicum), clove, and thyme EOs and nystatine on C. albicans growth resulted in similar inhibition zone diameters for cinnamon, clove, and nystatine [74].

C. albicans ATCC 28366 proved to be sensitive to cinnamon bark EO (C. zeylanicum) in another study [75]. The authors estimated MIC as ranging from $0.039 \%$ to $0.078 \%$, with an MFC of $0.078 \%$, which is a marker for the fungicidal properties of the EO. The inhibition of biofilm formation was obtained at $0.0049 \%$. Cinnamon EO did not exhibit any effect on the C. albicans adhesion to oral epithelial cells.

The antifungal effects of the EO of C. zeylanicum leaves (eugenol content $68.96 \%$ ) against several Candida spp., including reference strains and oral isolates of C. albicans, C. tropicalis, and C. krusei, showed a MIC from 62.5 to $1000 \mu \mathrm{g} / \mathrm{mL}$ and a MFC from 125 to $1000 \mu \mathrm{g} / \mathrm{mL}$ [76]. The MIC/MFC ratio was similar to that of nystatine. After exposure for $8 \mathrm{~h}$, a significant reduction in the fungal growth was observed up to a concentration of $750 \mu \mathrm{g} / \mathrm{mL}$. The suppression of biofilm formation at this concentration was also reported. Cinnamon EO was also able to reduce Candida spp. monospecies and multispecies in mature biofilm at 24 and $48 \mathrm{~h}$. This concentration is safe to use, since no significant reduction in the viability of human peripheral blood mononuclear cells was observed with concentrations of up to $1000 \mu \mathrm{g} / \mathrm{mL}$. 
Another study [77] of the antifungal activity of C. zeylanicum leaf EO (eugenol content 82.30\%) found that, at concentrations of 312.5 or $625.0 \mu \mathrm{g} / \mathrm{mL}$, all 12 tested strains of C. albicans and C. tropicalis were inhibited. At the same concentrations, the authors observed a fungicidal effect of cinnamon EO against all 12 strains, except one (MFC was 312.5 or $625.0 \mu \mathrm{g} / \mathrm{mL}$ ). The experimental mouth rinse, containing cinnamon $\mathrm{EO}$ at the $\mathrm{MIC}$, used in this study did not significantly change the surface roughness or the Vickers microhardness of the heat-polymerized acrylic resin in contrast to the nystatine group. Even at low concentrations, C. zeylanicum EO has an inhibitory effect against C. albicans. The authors reported a MIC of $0.005 \%(0.05 \mu \mathrm{l} / \mathrm{mL})$, an MFC of $0.01 \%$, and a $90 \%$ reduction in bacterial biofilm at $0.039 \%$ [61]. A MIC $<0.05 \mathrm{mg} / \mathrm{mL}$ for the methanolic extract of C. zeylanicum against $C$. albicans was reported in another study [78].

C. zeylanicum EO proved to be the most effective $\mathrm{EO}$ against $40 \mathrm{C}$. albicans isolates but to a lesser extent than the antifungal drugs and the mouthwashes [79]. A hydroalcoholic extract of C. zeylanicum was used to assess the antimycotic activity of cinnamon against fluconazole-resistant C. albicans. The MIC at a concentration of $15.62 \mu \mathrm{g} / \mathrm{mL}$ was reported [62]. The MIC and MFC at $65.5 \mu \mathrm{g} / \mathrm{mL}$ against C. albicans were reported by Cavalcanti et al. using C. cassia EO [80]. Khan et al. reported a MIC of $19.5 \mu \mathrm{g} / \mathrm{mL}$ and an MFC of $78 \mu \mathrm{g} / \mathrm{mL}$ against C. albicans ATCC-10231 [65].

Taguchi et al. studied the effects of C. cassia, S. aromaticum, and several other species and herbs against $C$. albicans in vitro and in an oral candidiasis murine model [81]. Cinnamon and clove hot water extracts inhibited the mycelial growth by $80 \%$ at concentrations of $1.0-5.0 \%$ and $5-25.0 \%$, respectively. The original C. cassia preparation inhibited the mycelial growth by $80 \%$ at concentrations of $36.5-146 \mu \mathrm{g} / \mathrm{mL}$. Only the $100 \%$ C. cassia preparation was able to improve the oral symptoms of candidiasis of the infected mice. Table 3 summarizes the data of the antifungal activity of cinnamon EO and cinnamon extracts.

Table 3. Minimal inhibitory concentration (MIC) and minimal fungicidal concentration (MFC) of cinnamon EO and cinnamon extracts.

\begin{tabular}{|c|c|c|c|c|c|}
\hline $\begin{array}{c}\text { Cinnamon } \\
\text { Species }\end{array}$ & EO or Extract & $\begin{array}{l}\text { Candida } \\
\text { Species }\end{array}$ & $\begin{array}{c}\text { MIC } \\
(\%)\end{array}$ & $\begin{array}{c}\text { MFC } \\
(\%)\end{array}$ & Reference \\
\hline C. zeylanicum & $\mathrm{EO}$ & $\begin{array}{l}\text { C. albicans } \\
\text { C. tropicalis } \\
\text { C. glabatra }\end{array}$ & $0.01-0.05$ & $0.01-0.05$ & [24] \\
\hline C. zeylanicum & $\mathrm{EO}$ & $\begin{array}{l}\text { C. albicans } \\
\text { C. glabatra }\end{array}$ & 5.12 & - & [73] \\
\hline C. zeylanicum & $\mathrm{EO}$ & $\begin{array}{l}\text { C. albicans } \\
\text { C. albicans, }\end{array}$ & $0.039-0.078$ & 0.078 & {$[75]$} \\
\hline C. zeylanicum & $\mathrm{EO}$ & $\begin{array}{c}\text { C. tropicalis } \\
\text { C. krusei }\end{array}$ & $0.006-0.1$ & $0.01-0.1$ & [76] \\
\hline C. zeylanicum & $\mathrm{EO}$ & $\begin{array}{l}\text { C. albicans, } \\
\text { C. tropicalis }\end{array}$ & $0.03-0.06$ & $0.03-0.06$ & [77] \\
\hline C. zeylanicum & $\mathrm{EO}$ & C. albicans & 0.005 & 0.01 & {$[61]$} \\
\hline C. zeylanicum & Methanolic extract & C. albicans & 0.005 & - & [78] \\
\hline C. zeylanicum & Hydroalcoholic extract & C. albicans & 0.001 & - & [62] \\
\hline C. cassia & $\mathrm{EO}$ & C. albicans & 0.006 & 0.006 & {$[80]$} \\
\hline C. zeylanicum & Ethanolic extract & C. albicans & 0.002 & 0.008 & {$[65]$} \\
\hline
\end{tabular}

\subsection{Antimicrobial Effect against Endopathogens}

Some studies focused on the antibacterial and antifungal effects of cinnamon EO and extracts against certain endodontic pathogens. The main cause of endodontic infection is the presence of microorganisms isolated as planktonic cells or biofilms [82]. Enterococcus faecalis is the most prevalent bacterium found in unsuccessful root canal treatments; some studies focused on the root canal irrigant efficiency against $C$. albicans $[83,84]$.

The antimicrobial effect of steam-distillated C. zeylanicum bark EO against E. faecalis ATCC 29212 was reported by Abbaszadegan et al. [85], with a MIC at $0.01 \mathrm{mg} / \mathrm{mL}$ and MBC at $0.1 \mathrm{mg} / \mathrm{mL}$. Cinnamon 
EO and the triple antibiotic paste used in the study were able to eliminate planktonic E. faecalis after 4 and $24 \mathrm{~h}$, while calcium hydroxide paste failed to do so. Cinnamon EO showed better biocompatibility with experimental fibroblast cells in comparison to the other two substances.

The MIC of C. zeylanicum exhibited against planktonic E. faecalis was 10\%, with complete bacterial inhibition after $30 \mathrm{~s}$ [86]. In a biofilm susceptibility assay on a cellulose nitrate membrane, complete bacterial inhibition was achieved after $12 \mathrm{~h}$, in contrast to the faster activity of $3 \%$ sodium hypochlorite $(\mathrm{NaOCl})$ of $2 \mathrm{~min}$. The effect of cinnamon $\mathrm{EO}$ as a root canal irrigant is weaker than $3 \% \mathrm{NaOCl}$ but could lead to $80-85 \%$ intracanal bacterial reduction [87]. A 20\% ethanolic extract of C. zeylanicum was found to be even more effective against E. faecalis ATCC 29212 compared to 3\% $\mathrm{NaOCl}$ [88]. The significant antimicrobial effect of C. cassia $\mathrm{EO}$ was proved against $C$. albicans and E. faecalis (MIC was $0.56 \mathrm{mg} / \mathrm{mL})$. A wider inhibition zone in comparison to chlorhexidine digluconate $(0.12 \%)$ and $1 \%$ sodium hypochlorite solutions was also observed [89]. Khan et al. reported MIC and MBC against E. faecalis ATCC-29212 at 95.7 and $1560 \mu \mathrm{g} / \mathrm{mL}$, respectively [65].

\subsection{Clinical Trials}

In clinical trials and systematic reviews, data on the advantageous effects of EO-containing mouth rinses on gingival inflammation can be found $[90,91]$. Only one clinical trial was conducted on the effects of cinnamon in dentistry.

The plaque reductive and anti-inflammatory effects of cinnamon extract were studied in comparison to chlorhexidine mouthwash. Although chlorhexidine showed the maximum decrease in both plaque and gingival scores, the cinnamon extract's effects were statistically insignificant [92].

\subsection{Other Studies against Oral Pathogens}

Cinnamon EO could be beneficial in halitosis treatment, since it reduced Solobacterium moorei biofilm formation, with MIC of $0.039 \%$ and MBC of $0.156 \%$ [93].

The antimicrobial effect of ethanolic extracts from C. zeylanicum and Salvadora persica against periodontal pathogens $P$. gingivalis, Tannerella forsythia, Treponema denticola, and A. actinomycetemcomitans was also studied. The results indicated the higher efficacy of cinnamon against all tested pathogens and the synergetic effect with antibiotics. The MIC ranged from 1.56 to $12.5 \mathrm{mg} / \mathrm{mL}$ and MBC from 6.25 to $75 \mathrm{mg} / \mathrm{mL}$ for different bacteria [94].

Bardají et al. investigated the antibacterial activity of C. zeylanicum $\mathrm{EO}$ against several oral pathogens. The MIC and MBC against Fusobacterium nucleatum, Actinomyces naeslundii, and Prevotella nigrescens were $125 \mu \mathrm{g} / \mathrm{mL}$; the MIC and MBC against S. mutans were 200 and $400 \mu \mathrm{g} / \mathrm{mL}$, respectively [95]. In contrast to many other studies, they did not detect cinnamaldehyde in the EO, and $(Z)$-isosafrole $(85.3 \%)$ was the main component.

C. zeylanicum EO proved to be more effective in comparison to C. zeylanicum bark aqueous extract against Staphylococcus auricularis, Acinetobacter lwoffii, C. albicans, and Micrococcus species that were collected and isolated from volunteers' oral cavities. C. zeylanicum EO was more effective than S. aromaticum EO, inhibiting the growth of all bacterial isolates [96]. This also indicates the activity of the experimental toothpaste used in the study containing: $35.00 \%$ calcium carbonate, $1.50 \%$ sodium lauryl sulfate, $30.00 \%$ glycerin, $1.00 \%$ sodium alginate, $00.12 \%$ sodium benzoate, $00.30 \%$ sodium saccharine, $2.50 \%$ plant extract, and purified water q.s.

Li et al. studied the antihalitosis effects of 40 Chinese herbs [97]. Fourteen herb extracts had volatile sulfur compound inhibition rates over 50\%. The extract from C. camphora proved to be not so effective in halitosis treatment in vitro, with a volatile sulfur compound inhibition rate of only $25.29 \%$ and a $50.14 \%$ microorganism inhibition rate. $\mathrm{Xu}$ patented a method for the production of chewing gum for the prevention and cure of decayed tooth and periodontitis with one of the active ingredients being Cinnamomum japonese extract [98].

Cinnamon EO could be useful in antibiotic treatments due to the possible synergetic effect. The combination of $C$. zeylanicum $\mathrm{EO}$ with amikacin showed a significant synergetic effect against 
Acinetobacter species with reduction of the MIC of amikacin [99]. The possible use of cinnamon bark $\mathrm{EO}$ as a modifying agent in the treatment of antibiotic-resistant bacteria was reported in combination with piperacillin [100].

\section{Main Constituents of Cinnamomum spp. and Their Antibacterial Properties against Oral Pathogens}

\subsection{Cinnamaldehyde}

Trans-Cinnamaldehyde ( $t$-Cinnamaldehyde or $(E)$-Cinnamaldehyde) was reported to be the main constituent of cinnamon EO and extracts. This molecule provides a major contribution to cinnamon's organoleptic and antibacterial properties.

Wang et al. studied the antibacterial effect of C. zeylanicum bark EO and its main constituent (57.97\% cinnamaldehyde) against $P$. gingivalis [101]. The authors confirmed that cinnamaldehyde is the constituent responsible for the antibacterial properties of $C$. zeylanicum, as it shows strong antibacterial effects; the MIC of the EO was $6.25 \mu \mathrm{g} / \mathrm{mL}$, and the MIC of cinnamaldehyde was $2.5 \mu \mathrm{M}$. The inhibitions of the P. gingivalis biofilm by $74.5 \%$ and $67.3 \%$, respectively, were also observed.

A study of the antimicrobial properties of the main constituents of C. zeylanicum EO showed that cinnamaldehyde was the most active against the two oral pathogens ( $S$. mutans and Streptococcus sobrinus), with inhibition zones ranging from 4.2 to $5.7 \mathrm{~cm}$. Eugenol and cinnamyl alcohol showed more effective activity against $S$. sobrinus in comparison to $S$. mutans. Both tested strains showed moderate sensitivity to 3 -carene, $\alpha$-Terpinene, benzaldehyde, linalool, $\beta$-Caryophyllene, $\alpha$-Humulene, $\alpha$-Terpineol, hydrocinnamic aldehyde, hydrocinnamyl acetate, and cinnamyl acetate. The MIC of cinnamaldehyde against both bacterial strains was $0.02 \%(v / v)$, whereas the MBCs against S. mutans and S. sorbinus were $0.2 \%$ and $0.1 \%(v / v)$, respectively [70]. C. zeylanicum, due to its main constituent $t$-Cinnamaldehyde, showed the highest antibacterial activity against several bacteria, with clinical significance among all the tested EOs (cumin (Cuminum cyminum), C. verum, cardamom (Amomum subulatum), and clove (S. aromaticum) [102]. In another study, the antimicrobial activity of cinnamaldehyde against Pseudomonas aeruginosa proved to be stronger than the antimicrobial activity of eugenol [103]. In a study by Pei, the MICs of cinnamaldehyde, thymol, and carvacrol alone against Escherichia coli were found to be $400 \mathrm{mg} / \mathrm{mL}$, whereas the MIC of eugenol was four times higher at $1600 \mathrm{mg} / \mathrm{mL}$ [104].

Cinnamaldehyde proved to have strong antifungal activity against the standard C. albicans strain and 26 oral isolates of C. albicans [105]. The in vitro antifungal effect against fluconazole-resistant C. albicans isolates (MIC $100-500 \mu \mathrm{g} / \mathrm{mL} ; 0.01-0.05 \%$ ) was also reported [106]. Taguchi et al. studied the antifungal activity of cinnamaldehyde and coumarin as the main compounds in a C. cassia preparation. A mycelial growth inhibition of $80 \%$ was achieved with $8.19-20.5 \mu \mathrm{g} / \mathrm{mL}$ of cinnamaldehyde and 128-320 $\mu \mathrm{g} / \mathrm{mL}$ of coumarin, which indicated that cinnamaldehyde has superior activity to that of coumarin. [81]. Firmino et al. compared the abilities of C. zeylanicum EO, C. cassia EO, and (E)-Cinnamaldehyde to reduce the biofilm biomass by $100 \%$ [32]. C. zeylanicum $\mathrm{EO}$ proved to be the most effective against E. coli, P. aeruginosa, and Streptococcus pyogenes. The three tested substances reduced the $S$. aureus biofilm at an equal concentration, $0.25 \%$, and only against Staphylococcus epidermidis did (E)-Cinnamaldehyde show better activity (the minimal concentration was two times lower than that of the two EOs tested). This means that the effect of the EO or its main constituent depends on the bacterial strain and the possible synergetic effects with the other constituents in the EOs.

\subsection{Eugenol}

Eugenol is another powerful substance present in cinnamon EO, although it is commonly associated with clove [107]. Since it is one of the most abundant compounds in cinnamon EO and extracts reported by some authors, its strong antimicrobial properties may play a significant role in oral health. 
The antimicrobial effect of eugenol against different oral pathogens and several modes of action have been reported. Eugenol showed a strong antibacterial effect against P. gingivalis ATCC 33277, with a MIC and MBC of 31.25 and $125 \mu \mathrm{M}$, respectively [108]. It destroyed the cell membrane in a dose-dependent manner, leading to cell shrinkage and death. Eugenol also reduced the biofilm formation of $P$. gingivalis and showed an ability to reduce the existing biofilm. A significant decrease in the expression of six virulence factor genes was also reported. A significant antibiofilm activity of eugenol against C. albicans and S. mutans was also observed in single and mixed biofilms [109]. Another study on the suppression effects of eugenol on biofilm- and quorum-sensing-related genes of S. mutans showed the significant effects of this compound at the sub-MIC [110]. The acid production and the synthesis of water-insoluble glucans by $S$. mutans were suppressed by eugenol. Eugenol also significantly inhibited the adherence of $S$. mutans to saliva-coated hydroxylapatite beads, and the effect was concentration-dependent. Eugenol treatment reduced the scores of smooth surfaces and sulcal caries in rats [111].

A comparative study of the antimicrobial effects of eugenol, $\beta$-Caryophyllene, and clove oil against several oral bacteria (S. mutans, Streptococcus sanguinis, S. sobrinus, Streptococcus ratti, Streptococcus criceti, Streptococcus anginosus, Streptococcus gordonii, A. actinomycetemcomitans, F. nucleatum, P. intermedia, and P. gingivalis) was conducted [112]. The MIC of eugenol and $\beta$-Caryophyllene varied from 0.1 to $0.8 \mathrm{mg} / \mathrm{mL}$ and from 0.8 to $12.8 \mathrm{mg} / \mathrm{mL}$, respectively. The MBC of eugenol was lower than that of $\beta$-Caryophyllene (0.1-0.8 and $1.6-12.8 \mathrm{mg} / \mathrm{mL}$, respectively). Eugenol showed a slightly stronger antibacterial activity in comparison to clove oil against some of the microorganisms. A synergistic effect with gentamicin and ampicillin was observed.

Eugenol nanoemulsion gel exhibited anti-inflammatory activity and analgesic and antibacterial effects, showing promise for the treatment of periodontal disease [113]. The antibacterial effect of zinc oxide eugenol paste against E. faecalis was confirmed [114].

\subsection{Linalool}

Park et al. studied the antibacterial properties of linalool and $\alpha$-Terpineol against several periodontopathogens and caries pathogens, including different strains from P. gingivalis, P. intermedia, Prevotela nidrescens, F. nucleatum, Aggregatibacter actinomycetemcomitans, S. mutans, and S. sobrinus [115]. The MIC of linalool against periodontal pathogens varied between 0.1 and $1.6 \mathrm{mg} / \mathrm{mL}$; with the exception of four out of 15 strains, the MIC was 0.1 or $0.2 \mathrm{mg} / \mathrm{mL}$. The MBC for all tested strains, except for two, was between 0.1 and $0.8 \mathrm{mg} / \mathrm{mL}$. One strain of $P$. gingivalis and one of $P$. nigrescens had an MBC of $1.6 \mathrm{mg} / \mathrm{mL}$. Linalool showed lower antibacterial activity against cariogenic bacteria, as the MIC and MBC ranged from 0.1 to $3.2 \mathrm{mg} / \mathrm{mL}$. Most of the 16 strains tested showed MIC and MBC values of $0.4 \mathrm{mg} / \mathrm{mL}$ and above, except for one strain of $S$. mutans $(0.1 \mathrm{mg} / \mathrm{mL}) . \alpha$-Terpineol showed MIC and MBC values against all tested periodontopathogens between 0.1 and $0.8 \mathrm{mg} / \mathrm{mL}$. The antimicrobial effect against cariogenic bacteria was slightly weaker, since the MIC and MBC varied between 0.4 and $1.6 \mathrm{mg} / \mathrm{mL}$, with the exception of the most sensitive against linalool, the $S$. mutans strain (MIC and $\mathrm{MBC}$ were $0.1 \mathrm{mg} / \mathrm{mL}$ ). Linalool and $\alpha$-Terpineol showed increased toxicity on the KB cell line at concentrations of $0.4 \mathrm{mg} / \mathrm{mL}$ and above, which should be their maximum concentration if used in toothpastes or mouthwashes.

\section{4. $\beta$-Caryophyllene}

The efficacy of $\beta$-Caryophyllene against $S$. mutans was reported [116]. The inhibitory effect of $\beta$-Caryophyllene on the growth of $S$. mutans started at concentrations above $0.078 \%$, and complete inhibition was observed at $0.32 \%$ and above. S. mutans biofilm formation was suppressed by $0.16 \%$ $\beta$-Caryophyllene. In a mature $S$. mutans biofilm, $1.25 \% \beta$-Caryophyllene exhibited disruptive and bactericidal activity. At a $0.039 \%$ concentration, $\beta$-Caryophyllene significantly inhibited the expression of $\mathrm{GtfB}$ and $\mathrm{GtfC}$ and reduced the expression of $\mathrm{GtfD}$, pointing to the mechanism of antibacterial action. 
The antibacterial activity of $\beta$-Caryophyllene against three periodontal pathogens, $P$. gingivalis, T. forsythia, and T. denticola, was also studied [117]. T. forsythia and P. gingivalis growth inhibitions were significant at concentrations of $0.019 \%$ and $0.004 \%$ and above, respectively. $\beta$-Caryophyllene interfered with lipopolysaccharide binding to CD14 or LBP, which resulted in inhibition of the induction of cytokine expression by lipopolysaccharides. A positive effect in volatile sulfur compounds reduction was also observed; thus, $\beta$-Caryophyllene could reduce halitosis.

\section{Discussion}

The review focused on the implications for cinnamon EO and extracts, as well as isolated bioactive compounds used in dental medicine. Since bacterial and fungal infections are the main causes of the most common dental diseases, the effects of cinnamon EO, cinnamon extracts, and the main compounds in treatments mainly depend on their antimicrobial and anti-inflammatory properties.

Few studies assessed the antibacterial effects of cinnamon EO and extracts against cariogenic bacteria, and approximately a dozen studies focused on the antifungal effect. Cinnamon has fungicidal and bactericidal effects based on the MIC, MBC, and MFC data. Wide ranges of MIC, MBC, and MFC have been reported, probably because different material sources and extraction methods were used. The mean values were calculated and are presented in Table 4 as percentages. The antifungal activity of cinnamon is more pronounced compared to its antibacterial properties, given the lower values of the MIC and MFC reported. Thus, cinnamon EO and cinnamon extracts could be useful in candidiasis treatments as the main or a complementary agent.

Table 4. The MIC, MBC, and MFC (\%) of cinnamon EO against oral pathogens (mean and standard deviation (SD)).

\begin{tabular}{ccccccc}
\hline & \multicolumn{2}{c}{ MIC } & \multicolumn{2}{c}{ MBC } & \multicolumn{2}{c}{ MFC } \\
\hline & Mean & SD & Mean & SD & Mean & SD \\
\hline Caries pathogens & 0.31 & 0.45 & 0.585 & 0.896 & - & - \\
\hline Candida spp. & 0.030 & 0.032 & - & - & 0.036 & 0.032 \\
\hline
\end{tabular}

Based upon these data, we conclude that cinnamon EO has strong antimicrobial effect against Candida spp. and moderate-to-weak effects against caries pathogens [7,60-62]. Still, the number of studies is low.

Cinnamon EO and extracts showed strong effects against endodontic pathogens. Thus, in certain cases, they can be used as an irrigant or as a temporary medicine on impregnated cotton pellet between clinical procedures. This would be appropriate in cases of a sodium hypochlorite allergy. They can also be added to zinc oxide formulations. Eugenol has already proved its antibacterial properties in dental medicine and has been used for centuries. Cinnamaldehyde, conversely, is not well-studied in endodontics. Further research on the positive effects of cinnamaldehyde-based medicines is needed.

To the best of our knowledge, only one clinical trial on the plaque reductive and anti-inflammatory effects of cinnamon extract in comparison to chlorhexidine mouthwash is described in the literature. Most of the other studies examined the antimicrobial effects of cinnamon and its main constituents in vitro. More in vivo studies would provide useful clinical information. Based on the antimicrobial properties, it seems reasonable to include cinnamon EO, cinnamon extracts, or major constituents in mouthwashes, toothpastes, and denture-cleansing solutions. Some authors proposed herbal dental toothpaste formulations that showed positive effects on plaque control, gingivitis, and halitosis [118,119]. One possible herbal dentifrice formulation was prepared by mixing $1 \mathrm{~g}$ of $\mathrm{NaHCO}_{3}$, two to three drops of essential peppermint oil, one drop clove of oil, $1 \mathrm{~mL}$ of coconut oil, and four to five drops of water [119]. Clove oil could be substituted with cinnamon EO.

Pure cinnamon compounds show different antimicrobial properties. The reported MIC of cinnamaldehyde against S. mutans and S. sorbinus was $0.02 \%(v / v)$, and the MBC was $0.2 \%$ and $0.1 \%$ 
$(v / v)$, respectively, which is in the range of the MIC against C. albicans $(0.01-0.05 \%)$ but is higher than the mean MIC of the cinnamon EO and extracts (Table 4). This suggests that cinnamaldehyde could be used as an alternative to cinnamon EO [32,70,106]. The antimicrobial effects of cinnamaldehyde and eugenol against $P$. gingivalis produced MICs of 2.5 and $31.25 \mu \mathrm{M}$, respectively $[101,108]$. The contribution of cinnamaldehyde to cinnamon's antimicrobial properties was reported in other studies [81,103]. Eugenol showed greater antibacterial activity against several oral pathogens in comparison to $\beta$-Caryophyllene, although the latter proved to be effective against $S$. mutans and even more efficient against $P$. gingivalis, Tannerella forsythia, and Treponema denticola [113,118,119]. Linalool and $\alpha$-Terpineol also proved effective against several periodontopathogens and caries pathogens, but their concentrations in toothpastes or mouthwashes should not exceed $0.04 \%$ [115].

Cinnamon EO, cinnamon extracts, and pure compounds exhibit significant antimicrobial properties; the choice of which in dental practice depends on different factors. EOs are natural and reachable solutions, but their properties depend on many factors, and their active ingredient contents are not constant $[120,121]$. There are seasonal changes in the contents, and the chemical compositions may vary considerably between species [122]. Thus, from a pharmaceutical point of view, if precise active ingredient concentrations is the goal, using pure compounds like cinnamaldehyde and eugenol seem to be the best alternatives. These substances could be included in certain formulations by dental material manufacturers. Since the effects of the EO depend on the interaction of all its ingredients, not only its main components, further investigations should be conducted to determine the synergetic effects between the pure compounds $[123,124]$. The compositions of the cinnamon extracts and their properties depend on the method used [59].

What cinnamon species or part of the plant should be used is another question that remains unanswered. Species high in cinnamaldehyde and eugenol and low in coumarin are preferable. A combination of leaf and bark EOs, due to the high cinnamaldehyde and eugenol contents, would contribute to the effective antimicrobial properties of the product. The studying and selection of certain chemo types seems reasonable. C. zeylanicum is one of the most-studied cinnamon species; it is generally safe to use and has shown good antimicrobial properties.

\section{Conclusions}

Cinnamon EO, cinnamon extracts, and the main components show significant antimicrobial activities against oral pathogens and could be beneficial in caries and periodontal disease prevention, endodontics, and candidiasis treatment. Further research focused on the clinical use of cinnamon EO-containing mouth care products should be conducted.

Funding: This research received no external funding.

Conflicts of Interest: The author declares no conflict of interest.

\section{References}

1. Kuang, X.; Chen, V.; Xu, X. Novel approaches to the control of oral microbial biofilms. BioMed Res. Int. 2018, 2018, 6498932. [CrossRef]

2. James, P.; Worthington, H.V.; Parnell, C.; Harding, M.; Lamont, T.; Cheung, A.; Whelton, H.; Riley, P. Chlorhexidine mouthrinse as an adjunctive treatment for gingival health. Cochrane Database Syst. Rev. 2017, 3, CD008676. [CrossRef] [PubMed]

3. Sheen, S.; Addy, M. An in vitro evaluation of the availability of cetylpyridinium chloride and chlorhexidine in some commercially available mouthrinse products. Br. Dent. J. 2003, 194, 207-210. [CrossRef]

4. Marinho, V.C.; Chong, L.Y.; Worthington, H.V.; Walsh, T. Fluoride mouthrinses for preventing dental caries in children and adolescents. Cochrane Database Syst. Rev. 2016, 7, CD002284. [CrossRef]

5. Mandava, K.; Batchu, U.R.; Kakulavaram, S.; Repally, S.; Chennuri, I.; Bedarakota, S.; Sunkara, N. Design and study of anticaries effect of different medicinal plants against S. mutans Glucosyltransferase. BMC Complement. Altern. Med. 2019, 19, 197. [CrossRef] 
6. Ashrafi, B.; Rashidipour, M.; Marzban, A.; Soroush, S.; Azadpour, M.; Delfani, S.; Ramak, P. Mentha piperita essential oils loaded in a chitosan nanogel with inhibitory effect on biofilm formation against $S$. mutans on the dental surface. Carbohydr. Polym. 2019, 212, 142-149. [CrossRef]

7. Wiwattanarattanabut, K.; Choonharuangdej, S.; Srithavaj, T. In vitro anti-cariogenic plaque effects of essential oils extracted from culinary herbs. J. Clin. Diagn. Res. 2017, 11, DC30-DC35. [CrossRef]

8. Beatović, D.; Krstić-Milošević, D.; Trifunović, S.; Šiljegović, J.; Glamočlija, J.; Ristić, M.; Jelačić, S. Chemical composition, antioxidant and antimicrobial activities of the essential oils of twelve Ocimum basilicum L. cultivars grown in Serbia. Rec. Nat. Prod. 2015, 9, 62-75.

9. Freires, I.A.; Denny, C.; Benso, B.; de Alencar, S.M.; Rosalen, P.L. Antibacterial activity of essential oils and their isolated constituents against cariogenic bacteria: A systematic review. Molecules 2015, 20, 7329-7358. [CrossRef] [PubMed]

10. Monawer, A. Elimination of oral pathogen. Int. J. Curr. Res. 2019, 11, 1862-1865.

11. Bakhtiari, S.; Jafari, S.; Taheri, J.B.; Kashi, T.S.J.; Namazi, Z.; Iman, M.; Poorberafeyi, M. The effects of Cinnamaldehyde (cinnamon derivatives) and Nystatin on Candida albicans and Candida glabrata. Open Access Maced. J. Med. Sci. 2019, 7, 1067-1070. [CrossRef] [PubMed]

12. Ardizzoni, A.; Pericolini, E.; Paulone, S.; Orsi, C.F.; Castagnoli, A.; Oliva, I.; Strozzi, E.; Blasi, E. In vitro effects of commercial mouthwashes on several virulence traits of Candida albicans, viridans streptococci and Enterococcus faecalis colonizing the oral cavity. PLoS ONE 2018, 13, e0207262. [CrossRef] [PubMed]

13. Kothiwale, S.V.; Patwardhan, V.; Gandhi, M.; Sohoni, R.; Kumar, A. A comparative study of antiplaque and antigingivitis effects of herbal mouthrinse containing tea tree oil, clove, and basil with commercially available essential oil mouthrinse. J. Indian Soc. Periodontol. 2014, 18, 316-320. [CrossRef] [PubMed]

14. Quintas, V.; Prada-López, I.; Donos, N.; Suárez-Quintanilla, D.; Tomás, I. Antiplaque effect of essential oils and $0.2 \%$ chlorhexidine on an in situ model of oral biofilm growth: A randomised clinical trial. PLoS ONE 2015, 10, e0117177. [CrossRef] [PubMed]

15. Subhashini, M.H.; Geetha, R.V. Action of tea tree oil and cinnamon leaf oil against oral pathogens. Asian J. Pharm. Clin. Res. 2015, 8, 79-80.

16. John, L.J.; Shantakumari, N. Herbal medicines use during pregnancy: A review from the Middle East. Oman Med. J. 2015, 30, 229-236. [CrossRef]

17. Wazaify, M.; Afifi, F.U.; El-Khateeb, M.; Ajlouni, K. Complementary and alternative medicine use among Jordanian patients with diabetes. Complement. Ther. Clin. Pract. 2011, 17, 71-75. [CrossRef]

18. Jaafarpour, M.; Hatefi, M.; Najafi, F.; Khajavikhan, J.; Khani, A. The effect of cinnamon on menstrual bleeding and systemic symptoms with primary dysmenorrhea. Iran. Red Crescent Med. J. 2015, 17, e27032. [CrossRef]

19. Kawatra, P.; Rajagopalan, R. Cinnamon: Mystic powers of a minute ingredient. Pharmacogn. Res. 2015, 7 (Suppl. 1), S1-S6. [CrossRef]

20. Jayaprakasha, G.K.; Rao, L.J. Chemistry, biogenesis, and biological activities of Cinnamomum zeylanicum. Crit. Rev. Food Sci. Nutr. 2011, 51,547-562. [CrossRef]

21. Chen, P.; Sun, J.; Ford, P. Differentiation of the four major species of cinnamons (C. burmannii, C. verum, C. cassia, and C. loureiroi) using a Flow Injection Mass Spectrometric (FIMS) fingerprinting method. J. Agric. Food Chem. 2014, 62, 2516-2521. [CrossRef] [PubMed]

22. Ravindran, P.; Shylaja, M.; Nirmal, B.K.; Krishnamoorthy, B. Botany and crop improvement of cinnamon and cassia. In Cinnamon and Cassia-The Genus Cinnamomum; Ravindran, P.N., Babu, K.N., Eds.; CRC Press: Boca Raton, FL, USA, 2004.

23. Gruenwald, J.; Freder, J.; Armbruester, N. Cinnamon and health. Crit. Rev. Food Sci. Nutr. 2010, 50, 822-834. [CrossRef] [PubMed]

24. Brochot, A.; Guilbot, A.; Haddioui, L.; Roques, C. Antibacterial, antifungal, and antiviral effects of three essential oil blends. Microbiologyopen 2017, 6, e00459. [CrossRef] [PubMed]

25. Zhang, Y.; Liu, X.; Wang, Y.; Jiang, P.; Quek, S.Y. Antibacterial activity and mechanism of cinnamon essential oil against Escherichia coli and Staphylococcus aureus. Food Control 2016, 59, 282-289. [CrossRef]

26. Teles, A.M.; Rosa, T.D.D.S.; Mouchrek, A.N.; Abreu-Silva, A.L.; Calabrese, K.D.S.; Almeida-Souza, F. Cinnamomum zeylanicum, Origanum vulgare, and Curcuma longa essential oils: Chemical composition, antimicrobial and antileishmanial activity. Evid. Based Complement. Altern. Med. 2019, 2019, 2421695. [CrossRef] [PubMed] 
27. Jayaprakasha, G.K.; Rao, L.J.M.; Sakariah, K.K. Chemical composition of the flower oil of Cinnamomum zeylanicum blume. J. Agric. Food Chem. 2000, 48, 4294-4295. [CrossRef] [PubMed]

28. Singh, G.; Maurya, S.; De Lampasona, M.P.; Catalan, C.A. A comparison of chemical, antioxidant and antimicrobial studies of cinnamon leaf and bark volatile oils, oleoresins and their constituents. Food Chem. Toxicol. 2007, 45, 1650-1661. [CrossRef] [PubMed]

29. Jayaprakasha, G.K.; Rao, L.J.; Sakariah, K.K. Chemical composition of the volatile oil from the fruits of Cinnamomum zeylanicum Blume. Flavour Fragr. J. 1997, 12, 331-333. [CrossRef]

30. Jayaprakasha, G.K.; Rao, L.J.; Sakariah, K.K. Chemical composition of volatile oil from Cinnamomum zeylanicum buds. Z. Nat. C J. Biosci. 2002, 57, 990-993. [CrossRef]

31. Jose, A.J.; Leela, N.K.; Zachariah, T.J.; Rema, J. Evaluation of coumarin content and essential oil constituents in Cinnamomum cassia (Nees \& T. Nees) J. Presl. J. Spices Aromat. Crops. 1970, 28, 43-51. [CrossRef]

32. Firmino, D.F.; Cavalcante, T.T.A.; Gomes, G.A.; Firmino, N.C.S.; Rosa, L.D.; De Carvalho, M.G.; Júnior, F.E.A.C. Antibacterial and Antibiofilm activities of Cinnamomum Sp. essential oil and Cinnamaldehyde: Antimicrobial activities. Sci. World J. 2018, 2018, 7405736. [CrossRef] [PubMed]

33. Yang, Z.; An, W.; Liu, S.; Huang, Y.; Xie, C.; Huang, S.; Zheng, X. Mining of candidate genes involved in the biosynthesis of dextrorotatory borneol in Cinnamomum burmannii by transcriptomic analysis on three chemotypes. Peer J. 2020, 8, e9311. [CrossRef] [PubMed]

34. Shan, B.; Cai, Y.Z.; Brooks, J.D.; Corke, H. Antibacterial properties and major bioactive components of cinnamon stick (Cinnamomum burmannii): Activity against foodborne pathogenic bacteria. J. Agric. Food Chem. 2007, 55, 5484-5490. [CrossRef] [PubMed]

35. Fajara, A.; Ammara, G.A.; Hamzaha, M.; Manurunga, R.; Abduha, M.Y. Effect of tree age on the yield, productivity, and chemical composition of essential oil from Cinnamomum burmannii. Curr. Res. Biosci. Biotechnol. 2019, 1, 17-22.

36. Daker, M.; Lin, V.Y.; Akowuah, G.A.; Yam, M.F.; Ahmad, M. Inhibitory effects of Cinnamomum burmannii Blume stem bark extract and trans-cinnamaldehyde on nasopharyngeal carcinoma cells; synergism with cisplatin. Exp. Ther. Med. 2013, 5, 1701-1709. [CrossRef] [PubMed]

37. Sakti, A.S.; Saputri, F.C.; Mun'im, A. Optimization of choline chloride-glycerol based natural deep eutectic solvent for extraction bioactive substances from Cinnamomum burmannii barks and Caesalpinia sappan heartwoods. Heliyon 2019, 5, e02915. [CrossRef]

38. Guo, X.; Cui, M.; Deng, M.; Liu, X.; Huang, X.; Zhang, X.; Luo, L.-P. Molecular differentiation of five Cinnamomum camphora chemotypes using desorption atmospheric pressure chemical ionization mass spectrometry of raw leaves. Sci. Rep. 2017, 7, 46579. [CrossRef]

39. Singh, V.; Gupta, A.K.; Singh, S.P.; Kumar, A. Direct analysis in real time by mass spectrometric technique for determining the variation in metabolite profiles of Cinnamomum tamala Nees and Eberm genotypes. Sci. World J. 2012, 2012, 549265. [CrossRef]

40. Wang, S.Y.; Yang, C.W.; Liao, J.W.; Zhen, W.W.; Chu, F.H.; Chang, S.T. Essential oil from leaves of Cinnamomum osmophloeum acts as a xanthine oxidase inhibitor and reduces the serum uric acid levels in oxonate-induced mice. Phytomedicine 2008, 15, 940-945. [CrossRef]

41. Lee, S.C.; Xu, W.X.; Lin, L.Y.; Yang, J.J.; Liu, C.T. Chemical composition and hypoglycemic and pancreas-protective effect of leaf essential oil from indigenous cinnamon (Cinnamomum osmophloeum Kanehira). J. Agric. Food Chem. 2013, 61, 4905-4913. [CrossRef]

42. Abdelwahab, S.I.; Mariod, A.A.; Taha, M.M.E.; Zaman, F.Q.; Abdelmageed, A.H.A.; Khamis, S.; Sivasothy, K.; Awang, K. Chemical composition and antioxidant properties of the essential oil of Cinnamomum altissimum Kosterm. (Lauraceae). Arab. J. Chem. 2017, 10, 131-135. [CrossRef]

43. Liang, Y.; Li, Y.; Sun, A.; Liu, X. Chemical compound identification and antibacterial activity evaluation of cinnamon extracts obtained by subcritical n-butane and ethanol extraction. Food Sci. Nutr. 2019, 7, 2186-2193. [CrossRef] [PubMed]

44. Liyanage, T.; Madhujith, T.; Wijesinghe, K.G.G. Comparative study on major chemical constituents in volatile oil of true cinnamon (Cinnamomum verum Presl. syn. C. zeylanicum Blum.) and five wild cinnamon species grown in Sri Lanka. Trop. Agric. Res. 2017, 28, 270-280. [CrossRef]

45. Doh, E.J.; Kim, J.H.; Oh, S.E.; Lee, G. Identification and monitoring of Korean medicines derived from Cinnamomum spp. by using ITS and DNA marker. Genes Genomics 2017, 39, 101-109. [CrossRef] [PubMed] 
46. Abraham, K.; Wöhrlin, F.; Lindtner, O.; Heinemeyer, G.; Lampen, A. Toxicology and risk assessment of coumarin: Focus on human data. Mol. Nutr. Food Res. 2010, 54, 228-239. [CrossRef] [PubMed]

47. Wang, Y.H.; Avula, B.; Nanayakkara, N.P.; Zhao, J.; Khan, I.A. Cassia cinnamon as a source of coumarin in cinnamon-flavored food and food supplements in the United States. J. Agric. Food Chem. 2013, 61, 4470-4476. [CrossRef] [PubMed]

48. Shreaz, S.; Wani, W.A.; Behbehani, J.M.; Raja, V.; Irshad, M.; Karched, M.; Ali, I.; Siddiqi, W.A.; Hun, L.T. Cinnamaldehyde and its derivatives, a novel class of antifungal agents. Fitoterapia 2016, 112, 116-131. [CrossRef] [PubMed]

49. Isaac-Renton, M.; Li, M.K.; Parsons, L.M. Cinnamon spice and everything not nice: Many features of intraoral allergy to cinnamic aldehyde. Dermatitis 2015, 26, 116-121. [CrossRef]

50. Calapai, G.; Miroddi, M.; Mannucci, C.; Minciullo, P.; Gangemi, S. Oral adverse reactions due to cinnamon-flavoured chewing gums consumption. Oral Dis. 2014, 20, 637-643. [CrossRef]

51. Vasconcelos, N.G.; Croda, J.; Simionatto, S. Antibacterial mechanisms of cinnamon and its constituents: A review. Microb. Pathog. 2018, 120, 198-203. [CrossRef]

52. Gupta, S.; Das, G. Clinical and radiographic evaluation of zinc oxide eugenol and metapex in root canal treatment of primary teeth. J. Indian Soc. Pedod. Prev. Dent. 2011, 29, 222-228. [CrossRef] [PubMed]

53. Campbell, T.M.; Neems, R.; Moore, J. Severe exacerbation of rosacea induced by cinnamon supplements. J. Drugs Dermatol. 2008, 7, 586-587. [PubMed]

54. Tremblay, S.; Avon, S.L. Contact allergy to cinnamon: Case report. J. Can. Dent. Assoc. 2008, 74, $445-461$. [PubMed]

55. Endo, H.; Rees, T.D. Cinnamon products as a possible etiologic factor in Orofacial Granulomatosis. Med. Oral Patol. Oral Cir. Bucal 2007, 12, E440-E444.

56. Ranasinghe, P.; Jayawardana, R.; Galappaththy, P.; Constantine, G.R.; de Vas Gunawardana, N.; Katulanda, P. Efficacy and safety of 'true' cinnamon (Cinnamomum zeylanicum) as a pharmaceutical agent in diabetes: A systematic review and meta-analysis. Diabet. Med. 2012, 29, 1480-1492. [CrossRef]

57. Ranasinghe, P.; Jayawardena, R.; Pigera, S.; Wathurapatha, W.S.; Weeratunga, H.D.; Premakumara, G.; Katulanda, P.; Constantine, G.R.; Galappaththy, P. Evaluation of Pharmacodynamic properties and safety of Cinnamomum zeylanicum (Ceylon cinnamon) in healthy adults: A phase I clinical trial. BMC Complement Altern. Med. 2017, 17, 550. [CrossRef]

58. Mendi, A.; Yağci, B.G.; Kiziloğlu, M.; Saraç, N.; Yilmaz, D.; Uğur, A.; Uçkan, D. Effects of Syzygium aromaticum, Cinnamomum zeylanicum, and salvia triloba extracts on proliferation and differentiation of dental pulp stem cells. J. Appl. Oral Sci. 2017, 25, 515-522. [CrossRef]

59. D'Souza, S.P.; Chavannavar, S.V.; Kanchanashri, B.; Niveditha, S.B. Pharmaceutical perspectives of spices and condiments as alternative antimicrobial remedy. J. Evid. Based Complement. Altern. Med. 2017, 22, 1002-1010. [CrossRef]

60. Duarte, M.C.; Leme, E.E.; Delarmelina, C.; Soares, A.A.; Figueira, G.M.; Sartoratto, A. Activity of essential oils from Brazilian medicinal plants on Escherichia coli. J. Ethnopharmacol. 2007, 111, 197-201. [CrossRef]

61. Hovijitra, R.S.; Choonharuangdej, S.; Srithavaj, T. Effect of essential oils prepared from Thai culinary herbs on sessile Candida albicans cultures. J. Oral Sci. 2016, 58, 365-371. [CrossRef]

62. Varadarajan, S.; Narasimhan, M.; Malaisamy, M.; Duraipandian, C. Invitro anti-mycotic activity of hydro alcoholic extracts of some Indian medicinal plants against fluconazole resistant Candida albicans. J. Clin. Diagn. Res. 2015, 9, ZC07-ZC10. [CrossRef] [PubMed]

63. Al-Radha, A.S.; Younes, C.; Diab, B.S.; Jenkinson, H.F. Essential oils and zirconia dental implant materials. Int. J. Oral Maxillofac. Implant. 2013, 28, 1497-1505. [CrossRef] [PubMed]

64. Elgamily, H.; Safy, R.; Makharita, R. Influence of medicinal plant extracts on the growth of oral pathogens Streptococcus mutans and Lactobacillus acidophilus: An in-vitro study. Open Access Maced. J. Med. Sci. 2019, 7, 2328-2334. [CrossRef] [PubMed]

65. Khan, R.; Islam, B.; Akram, M.; Shakil, S.; Ahmad, A.A.; Ali, S.M.; Siddiqui, M.; Khan, A.U. Antimicrobial activity of five herbal extracts against Multi Drug Resistant (MDR) strains of bacteria and fungus of clinical origin. Molecules 2009, 14, 586-597. [CrossRef] [PubMed]

66. Alshahrani, A.M.; Gregory, R.L. In vitro cariostatic effects of cinnamon water extract on nicotine-induced Streptococcus mutans biofilm. BMC Complement. Med. Ther. 2020, 20, 45. [CrossRef] 
67. Galvão, L.C.; Furletti, V.F.; Bersan, S.M.; Da Cunha, M.G.; Ruiz, A.; De Carvalho, J.E.; Sartoratto, A.; Rehder, V.L.G.; Figueira, G.M.; Duarte, M.C.T.; et al. Antimicrobial activity of essential oils against Streptococcus mutans and their antiproliferative effects. Evid. Based Complement. Altern. Med. 2012, 2012, 751435. [CrossRef]

68. Karadağlıŏlu, Ö.İ.; Ulusoy, N.; Başer, K.H.C.; Hanoğlu, A.; Şık, İ. Antibacterial activities of herbal toothpastes combined with essential oils against Streptococcus mutans. Pathogens 2019, 8, 20. [CrossRef]

69. Chaudhari, L.K.; Jawale, B.A.; Sharma, S.; Sharma, H.; Kumar, C.D.; Kulkarni, P.A. Antimicrobial activity of commercially available essential oils against Streptococcus mutans. J. Contemp. Dent. Pract. 2012, 13, 71-74. [CrossRef]

70. Choi, O.; Cho, S.K.; Kim, J.; Park, C.G.; Kim, J. In vitro antibacterial activity and major bioactive components of Cinnamomum verum essential oils against cariogenic bacteria, Streptococcus mutans and Streptococcus sobrinus. Asian Pac. J. Trop. Biomed. 2016, 6, 308-314. [CrossRef]

71. Filoche, S.K.; Soma, K.; Sissons, C.H. Antimicrobial effects of essential oils in combination with chlorhexidine digluconate. Oral Microbiol. Immunol. 2005, 20, 221-225. [CrossRef]

72. Alexa, V.T.; Galuscan, A.; Popescu, I.; Tirziu, E.; Obistioiu, D.M.; Floare, A.D.; Perdiou, A.; Jumanca, D. Synergistic/antagonistic potential of natural preparations based on essential oils against Streptococcus mutans from the oral cavity. Molecules 2019, 24, 4043. [CrossRef] [PubMed]

73. Fani, M.M.; Kohanteb, J. Inhibitory activity of cinnamon Zeylanicum and eucalyptus Globulus oils on Streptococcus mutans, Staphylococcus aureus, and candida species isolated from patients with oral infections. Shiraz Univ. Dent. J. 2011, 11, 14.

74. SHerzaee, M.; Poorzamani, M. Inhibitory effects of plant extracts containing thyme, Clore and cinnamon compared to Nystatin on Candida albicans. (In Vitro). Res. Dent. Sci. 2012, 8, 175-179.

75. Veilleux, M.P.; Grenier, D. Determination of the effects of cinnamon bark fractions on Candida albicans and oral epithelial cells. BMC Complement. Altern. Med. 2019, 19, 303. [CrossRef] [PubMed]

76. Rangel, M.L.; de Aquino, S.G.; de Lima, J.M.; Castellano, L.R.; de Castro, R.D. In vitro effect of Cinnamomum zeylanicum Blume essential oil on Candida spp. involved in oral infections. Evid. Based Complement. Altern. Med. 2018, 2018, 4045013. [CrossRef] [PubMed]

77. Oliveira, J.d.A.; da Silva, I.C.; Trindade, L.A.; Lima, E.O.; Carlo, H.L.; Cavalcanti, A.L.; De Castro, R.D. Safety and tolerability of essential oil from Cinnamomum zeylanicum Blume leaves with action on oral Candidosis and its effect on the physical properties of the acrylic resin. Evid. Based Complement. Altern. Med. 2014, 2014, 325670. [CrossRef]

78. Latti, P.; Ramanarayanan, S.; Prashant, G.M. Antifungal efficacy of spice extracts against Candida albicans: An in vitro study. Indian J. Community Med. 2019, 44 (Suppl. 1), S77-S80. [CrossRef]

79. Carvalhinho, S.; Costa, A.M.; Coelho, A.C.; Martins, E.; Sampaio, A. Susceptibilities of Candida albicans mouth isolates to antifungal agents, essentials oils and mouth rinses. Mycopathologia 2012, 174, 69-76. [CrossRef]

80. Almeida, L.d.F.; Paula, J.F.; Almeida, R.V.; Williams, D.W.; Hebling, J.; Cavalcanti, Y.W. Efficacy of citronella and cinnamon essential oils on Candida albicans biofilms. Acta Odontol. Scand. 2016, 74, 393-398. [CrossRef]

81. Taguchi, Y.; Takizawa, T.; Ishibashi, H.; Sagawa, T.; Arai, R.; Inoue, S.; Yamaguchi, H.; Abe, S. Therapeutic effects on murine oral candidiasis by oral administration of cassia (Cinnamomum cassia) preparation. Nihon Ishinkin Gakkai Zasshi 2010, 51, 13-21. [CrossRef]

82. Prada, I.; Micó-Muñoz, P.; Giner-Lluesma, T.; Micó-Martínez, P.; Collado-Castellano, N.; Manzano-Saiz, A. Influence of microbiology on endodontic failure. Literature review. Med. Oral Patol. Oral. Cir. Bucal 2019, 24, e364-e372. [CrossRef] [PubMed]

83. Medvedec, M.I.; Cigić, L.; Kero, D.; Govorko, D.K.; Mehičić, G.P.; Andrašević, A.T.; Simeon, P. Antimicrobial effectiveness of Polyhexamethylene Biguanide on Enterococcus faecalis, Staphylococcus epidermidis and Candida albicans. Med. Glas. 2018, 15, 132-138. [CrossRef]

84. Singh, M.; Singh, S.; Salgar, A.R.; Prathibha, N.; Chandrahari, N.; Swapna, L.A. An in vitro comparative evaluation of antimicrobial efficacy of Propolis, Morinda Citrifolia juice, sodium hypochlorite and Chlorhexidine on Enterococcus faecalis and Candida albicans. J. Contemp. Dent. Pract. 2019, 20, 40-45. [PubMed]

85. Abbaszadegan, A.; Dadolahi, S.; Gholami, A.; Moein, M.R.; Hamedani, S.; Ghasemi, Y.; Abbott, P.V.; Patil, S. Antimicrobial and cytotoxic activity of Cinnamomum zeylanicum, Calcium hydroxide, and triple antibiotic paste as root canal dressing materials. J. Contemp. Dent. Pract. 2016, 17, 105-113. [CrossRef] 
86. Gupta, A.; Duhan, J.; Tewari, S.; Sangwan, P.; Yadav, A.; Singh, G.; Juneja, R.; Saini, H. Comparative evaluation of antimicrobial efficacy of Syzygium aromaticum, Ocimum sanctum and Cinnamomum zeylanicum plant extracts against Enterococcus faecalis: A preliminary study. Int. Endod. J. 2013, 46, 775-783. [CrossRef]

87. Gupta-Wadhwa, A.; Wadhwa, J.; Duhan, J. Comparative evaluation of antimicrobial efficacy of three herbal irrigants in reducing intracanal, E. faecalis populations: An in vitro study. J. Clin. Exp. Dent. 2016, 8, e230-e235. [CrossRef]

88. Panchal, V.; Gurunathan, D.; Muralidharan, N.P. Comparison of antibacterial efficacy of cinnamon extract, Neem extract as irrigant and sodium hypochlorite against Enterococcus fecalis: An in vitro study. Indian J. Dent. Res. 2020, 31, 124-128. [CrossRef]

89. Cavalcanti, Y.W.; Pérez, A.L.A.L.; Xavier, G.D.R.; de Almeida, L.d.F.D. Inhibitory effect of essential oils against organisms from root canal. Rev. Odontol. UNESP 2011, 40, 208-214.

90. Richards, D. Effect of essential oil mouthwashes on plaque and gingivitis. Evid. Based Dent. 2017, 18, 39-40. [CrossRef]

91. Charles, C.H.; Mostler, K.M.; Bartels, L.L.; Mankodi, S.M. Comparative antiplaque and antigingivitis effectiveness of a Chlorhexidine and an essential oil mouthrinse: 6-month clinical trial. J. Clin. Periodontol. 2004, 31, 878-884. [CrossRef]

92. Gupta, D.; Jain, A. Effect of cinnamon extract and Chlorhexidine Gluconate $(0.2 \%)$ on the clinical level of dental plaque and gingival health: A 4-week, triple-blind randomized controlled trial. J. Int. Acad. Periodontol. 2015, 17, 91-98. [PubMed]

93. LeBel, G.; Haas, B.; Adam, A.A.; Veilleux, M.P.; Lagha, A.B.; Grenier, D. Effect of cinnamon (Cinnamomum verum) bark essential oil on the halitosis-associated bacterium Solobacterium moorei and in vitro cytotoxicity. Arch. Oral Biol. 2017, 83, 97-104. [CrossRef] [PubMed]

94. Saquib, S.A.; AlQahtani, N.A.; Ahmad, I.; Kader, M.A.; Al Shahrani, S.S.; Asiri, E.A. Evaluation and comparison of antibacterial efficacy of herbal extracts in combination with antibiotics on periodontal pathobionts: An in vitro microbiological study. Antibiotics 2019, 8, 89. [CrossRef] [PubMed]

95. Bardají, D.K.; Reis, E.B.; Medeiros, T.C.; Lucarini, R.; Crotti, A.E.; Martins, C.H. Antibacterial activity of commercially available plant-derived essential oils against oral pathogenic bacteria. Nat. Prod. Res. 2016, 30, 1178-1181. [CrossRef]

96. Parthasarathy, H.; Thombare, S. Evaluation of antimicrobial activity of Azadirachta indica, Syzygium aromaticum and Cinnamomum zeyalnicumagainst oral microflora. Asian J. Exp. Sci. 2013, 27, 13-16.

97. Li, M.Y.; Wang, J.; Xu, Z.T. Effect of a variety of Chinese herbs and an herb-containing dentifrice on volatile sulfur compounds associated with halitosis: An in vitro analysis. Curr. Ther. Res. Clin. Exp. 2010, 71, 129-140. [CrossRef]

98. Xu, Y. Production Method of Chewing Gum and Bubble Gum Capable of Preventing and Treating Decayed Tooth and Periodontitis. Patent Number CN 1994116766, 24 January 1996.

99. Guerra, F.Q.; Mendes, J.M.; Sousa, J.P.; Morais-Braga, M.F.; Santos, B.H.C.; Coutinho, H.D.M.; Lima, E.D.O. Increasing antibiotic activity against a multidrug-resistant Acinetobacter spp by essential oils of Citrus limon and Cinnamomum zeylanicum. Nat. Prod. Res. 2012, 26, 2235-2238. [CrossRef]

100. Yap, P.S.; Lim, S.H.; Hu, C.P.; Yiap, B.C. Combination of essential oils and antibiotics reduce antibiotic resistance in plasmid-conferred multidrug resistant bacteria. Phytomedicine 2013, 20, 710-713. [CrossRef]

101. Wang, Y.; Zhang, Y.; Shi, Y.Q.; Pan, X.H.; Lu, Y.H.; Cao, P. Antibacterial effects of cinnamon (Cinnamomum zeylanicum) bark essential oil on Porphyromonas gingivalis. Microb. Pathog. 2018, 116, 26-32. [CrossRef]

102. Naveed, R.; Hussain, I.; Tawab, A.; Tariq, M.; Rahman, M.; Hameed, S.; Mahmood, M.S.; Siddique, A.B.; Iqbal, M. Antimicrobial activity of the bioactive components of essential oils from Pakistani spices against Salmonella and other multi-drug resistant bacteria. BMC Complement. Altern. Med. 2013, 13, 265. [CrossRef]

103. Utchariyakiat, I.; Surassmo, S.; Jaturanpinyo, M.; Khuntayaporn, P.; Chomnawang, M.T. Efficacy of cinnamon bark oil and cinnamaldehyde on anti-multidrug resistant Pseudomonas aeruginosa and the synergistic effects in combination with other antimicrobial agents. BMC Complement. Altern. Med. 2016, 16, 158. [CrossRef] [PubMed]

104. Pei, R.S.; Zhou, F.; Ji, B.P.; Xu, J. Evaluation of combined antibacterial effects of eugenol, cinnamaldehyde, thymol, and carvacrol against E. coli with an improved method. J. Food Sci. 2009, 74, M379-M383. [CrossRef] [PubMed] 
105. Shreaz, S.; Bhatia, R.; Khan, L.A.; Khan, N.; Maurya, I.K.; Ahmad, S.I.; Muralidhar, S.; Manzoor, N. Cinnamic aldehydes affect hydrolytic enzyme secretion and morphogenesis in oral Candida isolates. Microb. Pathog. 2012, 52, 251-258. [CrossRef] [PubMed]

106. Shreaz, S.; Bhatia, R.; Khan, L.A.; Khan, N.; Muralidhar, S.; Basir, S.F.; Manzoor, N. Spice oil cinnamaldehyde exhibits potent anticandidal activity against fluconazole resistant clinical isolates. Fitoterapia 2011, 82, 1012-1020. [CrossRef] [PubMed]

107. Chaieb, K.; Hajlaoui, H.; Zmantar, T.; Rouabhia, M.; Mahdouani, K.; Bakhrouf, A.; Ben Kahla-Nakbi, A. The chemical composition and biological activity of clove essential oil, Eugenia caryophyllata (Syzigium aromaticum L. Myrtaceae): A short review. Phytother. Res. 2007, 21, 501-506. [CrossRef] [PubMed]

108. Zhang, Y.; Wang, Y.; Zhu, X.; Cao, P.; Wei, S.; Lu, Y. Antibacterial and antibiofilm activities of eugenol from essential oil of Syzygium aromaticum (L.) Merr. \& L. M. Perry (clove) leaf against periodontal pathogen Porphyromonas gingivalis. Microb. Pathog. 2017, 113, 396-402. [CrossRef]

109. Jafri, H.; Khan, M.S.A.; Ahmad, I. In vitro efficacy of eugenol in inhibiting single and mixed-biofilms of drug-resistant strains of Candida albicans and Streptococcus mutans. Phytomedicine 2019, 54, 206-213. [CrossRef]

110. Adil, M.; Singh, K.; Verma, P.K.; Khan, A.U. Eugenol-induced suppression of biofilm-forming genes in Streptococcus mutans: An approach to inhibit biofilms. J. Glob. Antimicrob. Resist. 2014, 2, 286-292. [CrossRef]

111. Xu, J.S.; Li, Y.; Cao, X.; Cui, Y. The effect of eugenol on the cariogenic properties of Streptococcus mutans and dental caries development in rats. Exp. Ther. Med. 2013, 5, 1667-1670. [CrossRef]

112. Moon, S.E.; Kim, H.Y.; Cha, J.D. Synergistic effect between clove oil and its major compounds and antibiotics against oral bacteria. Arch. Oral Biol. 2011, 56, 907-916. [CrossRef]

113. Ahmad, N.; Ahmad, F.J.; Bedi, S.; Sharma, S.; Umar, S.; Ansari, M.A. A novel Nanoformulation development of Eugenol and their treatment in inflammation and periodontitis. Saudi Pharm. J. 2019, 27, 778-790. [CrossRef]

114. Jaidka, S.; Somani, R.; Singh, D.J.; Sheikh, T.; Chaudhary, N.; Basheer, A. Herbal combat against E. faecalis-An in vitro study. J. Oral Biol. Craniofacial Res. 2017, 7, 178-181. [CrossRef] [PubMed]

115. Park, S.N.; Lim, Y.K.; Freire, M.O.; Cho, E.; Jin, D.; Kook, J.K. Antimicrobial effect of linalool and $\alpha$-terpineol against periodontopathic and cariogenic bacteria. Anaerobe 2012, 18, 369-372. [CrossRef] [PubMed]

116. Yoo, H.J.; Jwa, S.K. Inhibitory effects of $\beta$-caryophyllene on Streptococcus mutans biofilm. Arch. Oral Biol. 2018, 88, 42-46. [CrossRef]

117. Yoo, H.J.; Jwa, S.K. Efficacy of $\beta$-caryophyllene for periodontal disease related factors. Arch. Oral Biol. 2019, 100, 113-118. [CrossRef]

118. Pentapati, K.C.; Kukkamalla, M.A.; Siddiq, H.; Sabnis, N. Effectiveness of novel herbal dentifrice in control of plaque, gingivitis, and halitosis—Randomized controlled trial. J. Tradit. Complement. Med. 2019. [CrossRef]

119. Shanmugapriya, R.; Arunmozhi, U.; Kadhiresan, R.; Sabitha, S.; Anirudhya, R.; Sujatha, G. Comparison of antiplaque effectiveness of herbal toothpaste: A randomized triple-blinded cross-over clinical trial. AYU 2019, 40, 109-113. [CrossRef] [PubMed]

120. Rehman, S.U.; Ahmad, M.M.; Kazmi, Z.H.; Raza, M.S. Physico-chemical variations in essential oils of citrus reticulata. J. Food Sci. Technol. 2007, 44, 353-356.

121. Angioni, A.; Barra, A.; Coroneo, V.; Dessi, S.; Cabras, P. Chemical composition, seasonal variability, and antifungal activity of Lavandula stoechas L. ssp. stoechas essential oils from stem/leaves and flowers. J. Agric. Food Chem. 2006, 54, 4364-4370. [CrossRef]

122. Lin, C.; Yeh, T.; Cheng, S.; Chang, S. Complementary relationship between trans-cinnamaldehyde and trans-cinnamyl acetate and their seasonal variations in Cinnamomum osmophloeum ct. cinnamaldehyde. Ind. Crop. Prod. 2019, 127, 172-178. [CrossRef]

123. Tak, J.H.; Isman, M.B. Penetration-enhancement underlies synergy of plant essential oil Terpenoids as insecticides in the cabbage Looper, Trichoplusia ni. Sci. Rep. 2017, 7, 42432. [CrossRef] [PubMed]

124. Tak, J.H.; Isman, M.B. Enhanced Cuticular penetration as the mechanism for synergy of insecticidal constituents of rosemary essential oil in Trichoplusia ni. Sci. Rep. 2015, 5, 12690. [CrossRef] [PubMed]

(C) 2020 by the author. Licensee MDPI, Basel, Switzerland. This article is an open access article distributed under the terms and conditions of the Creative Commons Attribution (CC BY) license (http://creativecommons.org/licenses/by/4.0/). 